\title{
THE PERFORMATIVE TURN AT INHOTIM: installation art and Baudelairean modernity
}

\author{
A VIRADA PERFORMATIVA EM INHOTIM: AS INSTALAÇÕES E A \\ MODERNIDADE BAUDELAIRIANA
}

\author{
Lauren Weingarden \\ Florida State University, EUA
}

\begin{abstract}
A BSTRACT
This article explores the participatory turn in installation art as part of a trajectory from Baudelairean modernity to twentyfirst-century postmodernity, as represented at Inhotim, the outdoor contemporary art museum and botanical gardens in Brumadinho, MG. In his 1862 essay "The Painter of Modern Life," Charles Baudelaire defined modernity as fleeting, transitory and fragmentary. Baudelairean modernity initiated a breakdown of boundaries between art and life and between high art aesthetics and popular culture, which continues in the work of installation artists. In the sites of installation art, the spectator is compelled to extend - rather than complete - the work of art in his/her own time, prior experiential encounters and transformative afterthoughts. The shift from the isolated work of art to the experiential one not only complicates how and where works of art are viewed, but also radicalizes the materials that constitute the work of art - whether those materials are extracted from the quotidian sphere or complex technologies, each undergoes a process of defamiliarization and reactivation to produce the transformative aesthetic experience. The individual installations in Inhotim's "outdoor museum" engage the spectator in a dynamic/participatory experience with spatial, temporal and material relationships that define the very essence of art's reciprocity, or contrast with the natural and man-made worlds. It is the rarefied setting of Inhotim's botanical gardens that makes the participatory and transformative experience central to the aesthetic encounter with installation art.
\end{abstract}

KEYWORDS

Inhotim, Installation Art, Baudelairean modernity, postmodernity

\footnotetext{
${ }^{1}$ lweingarden@fsu.edu
} 
Inhotim Institute of Contemporary Art and Botanical Gardens (FIG. 1) was founded in 2004 by the mining magnate Bernardo Paz, and opened to the public in 2006. ${ }^{2}$ Paz's contemporary art collection is displayed throughout the 3000 acres of botanical gardens situated in the forest and hills of the surrounding iron-mining terrain. Inhotim is located on the outskirts of the small town of Brumadinho, thirty-seven miles from Belo Horizonte, the capital of Minas Gerais. The Inhotim Institute of Contemporary Art is a unique museological institution for its collection of installation art, three-dimensional artworks that are experienced as singular spatial entities, at times open or closed, site-specific or transportable. At the time of this writing, there are more than twenty individual pavilions, housing single installations, dispersed throughout the gardens and forest clearings, while over fifteen freestanding creations are exposed to the elements.

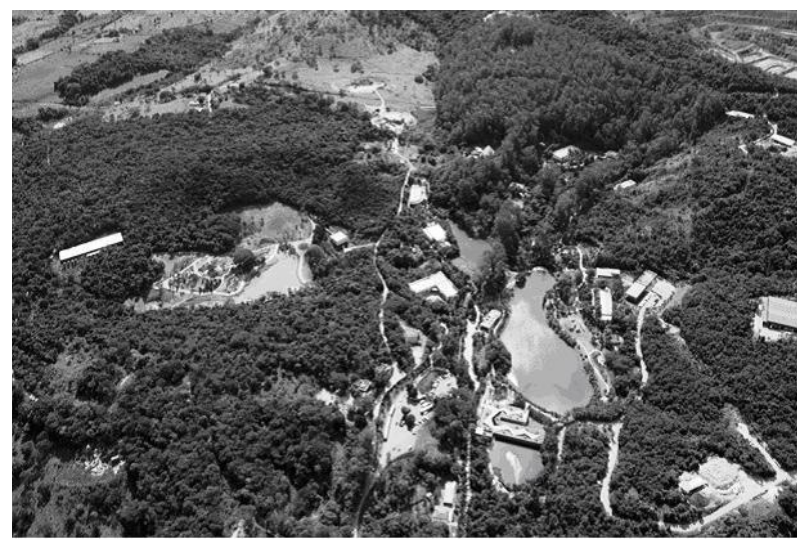

Figure 1 - Inhotim Institute of Contemporary Art and Botanical Gardens, Brumadinho, aerial view Source: $<$ http://curatorsintl.org/intensive $>$.

In this article I trace the performative turn in installation art as part of a historical trajectory that issues from nineteenth-century modernity to twenty-first century postmodernity. Charles Baudelaire's 1859 essay, "The Painter of Modern Life," marks the starting point of this development and Inhotim marks its present-day culmination. Central to this trajectory is the transformational function of the work of art; by this I mean that by way of sensory and transitory aesthetic experiences induced in the viewer, the art work changes our perception and comprehension of the world. As we will see, this trajectory marks a shift from the viewer's imagined movement when viewing an artwork to his actual movement through the artwork. The shift also involves the viewer's increased role in contributing to the artwork's meaning. While Baudelaire defined this new aesthetic of engagement within the context of modern Paris, the rarefied setting of Inhotim's botanical gardens and landscape magnifies the participatory and transformative experience that is central to the aesthetic encounter with its Installation art collection.

To historically connect Baudelairean modernity with Inhotim I trace four themes through which the spectator's transformational and performative experiences are activated by modern

\footnotetext{
${ }^{2}$ For a brief history of the collection and short essays on selected artworks see: SCHWARTZMAN et al. (Ed.). Through: Inhotim.
} 
and contemporary art: 1) transitoriness; 2) fragmentation; 3) decentering and displacement of the viewing subject; 4) defamiliarization of the familiar. ${ }^{3}$

\section{The Baudelairean Inception: Nineteenth-Century Paris and the Birth of Modernity}

In "The Painter of Modern Life," Baudelaire defined modernity as fleeting, transitory and fragmentary. Written in 1859, Baudelaire defined modernity within the context of the widespread demolition and rebuilding of Paris at mid-century. Under the direction of Napoleon III and his planner Baron Georges-Eugène Haussmann, old Paris was demolished and modern Paris was born. From here, Baudelaire prescribed an aesthetic of dualities and self-doubling as the visceral response to the urban experience and its expression in artistic form. For Baudelaire, the new art must transform the familiar into the unfamiliar, must render embodied experiences of change in fragmented forms, and transmit the transience of urban life to the viewer's psyche. Accordingly, Baudelaire defined the "double composition" of modern beauty as a constant tension between "an eternal, invariable element," and "a relative circumstantial element [of] contemporaneity." Baudelaire prescribed that the artist achieve this aesthetic dualism and, ultimately, cultural renewal, by triggering in the viewer "the shock of surprise." The new and beautiful, he writes, is "always strange". 5 The artist achieves these shocking effects by rendering the familiar unfamiliar; that is, by presenting, in Baudelaire's words, "the ever-new which [always] elud[e]s," but still refers to, "the rules and analyses of the school." Baudelaire further instructed how to make the ordinary extraordinary, urging the artist to discover "the heroism of our day," not in ancient history and myths, but in "the scenes of high life and of the thousands of uprooted lives that haunt the underworld of a great city."

For Baudelaire it was mandatory that the artist re-present his sensory experience of modern life in the work of art so that the viewer re-experiences the visceral effects of infinite transitoriness. To this end, the artist must submerge himself in the urban crowd and embody its vital essence. Baudelaire thus proclaims: "The crowd is his [the artist's] domain, [he] establish[es] his dwelling in the throng, in the ebb and flow, the bustle, the fleeting and the infinite." As the embodiment of the crowd, Baudelaire explains, the artist "may also be compared to a mirror as vast as this crowd; to a kaleidoscope endowed with consciousness, which with every one of its movements presents a pattern of life, in all its multiplicity." ${ }^{8}$ For Baudelaire, the creative process begins when the artist loses himself in the flux of the urban ambience. In the next stage, the artist must distance himself to reflect upon the capacity of his medium to trigger the viewer's self-reflection upon the multifarious modern conditions. Therefore, Baudelaire suggests how

\footnotetext{
${ }^{3}$ BISHOP's Installation Art: A Critical History is a primer on this contemporary art genre and the experiential aesthetic. My argument regarding the embodied experience encountered in Installation art follows a different genealogy by focusing on the Baudelairean strain of modernity.

${ }^{4}$ BAUDELAIRE. The Painter of Modern Life, p. 392.

${ }^{5}$ BAUDELAIRE. The Exposition Universelle (1855), p. 124.

${ }^{6}$ BAUDELAIRE. The Exposition Universelle (1855), p. 124. "The rules and analyses of the school" refers to traditional subjects and techniques, as seen in Jacques-Louis David's Oath of Horatii, 1784, Musée du Louvre, Paris.

${ }^{7}$ BAUDELAIRE. Salon of 1846: XVII of the Heroism of Modern Life, p. 104.

${ }^{8}$ BAUDELAIRE. The Painter of Modern Life, p. 400.
} 
the artist can transmit his lived experience to the viewer through an artistic technique that is itself fleeting and fragmented, since such a technique must "reflect [the artist's consciousness] at every moment in energies, more vivid than life itself, always inconstant and fleeting."

In order to initiate and sustain the viewer's comprehension of modernity, Baudelaire's artistic followers sought to put the viewer at the center of the pictorial space so as to engage him/her in the transitory experience that initiated the artist's creative response to modernity. Here we can consider the work of one such artist: Édouard Manet's A Bar at the Folies Bergère (1881-82, FIG. 2) demonstrates how the modern artist eliminated one-point perspective in order to decenter the viewer and represent his place within the dynamic picture space. Briefly stated, one-point perspective is a mathematical system for representing three-dimensional objects and space on a two-dimensional surface by means of intersecting lines that are drawn vertically and horizontally and that radiate from one point. This technique, developed in the fifteenth-century Italian renaissance, is what makes a painted scene look like an extension of actual space into deep pictorial space. One-point perspective depends on the viewer's fixed position in front and center of the artwork. However, by the mid-nineteenth-century those artists who wanted to depict modern experiences found these illusionistic techniques artificial, predictable and static.

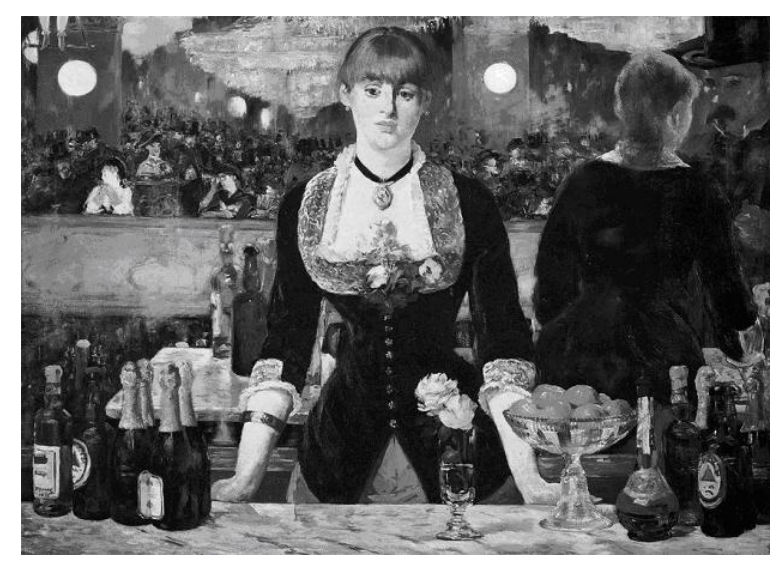

Figure 2 - Edouard Manet, A Bar at the Folies-Bergère, 1881-82. Oil on canvas, $96 \times 130 \mathrm{~cm}$. Courtauld Institute of Art, London Source: ARTStor Image Gallery.

As seen in Manet's painted mirror, fragmentation and sketch-like brushwork have "surprise" effects. These techniques shock the viewer because they contradict expectations for the finished, illusionistic work of art. The painted mirror also shocks by denying the viewer's traditional way of entering the painting through one-point perspective and an illusionistic extension of the objects' and figures' space. Likewise, the barmaid's reflection does not line up with her actual figure and the reflected man's figure is omitted from the front of the bar where he should be standing. These distortions aside, the painted mirror presents a kaleidoscopic view of a thoroughly modern venue. The Folies Bergère, a popular Parisian cabaret, was a new urban space where high life and low life converged in a dynamic spectacle of lights, costumes and actors' and viewers' animations. Commonplace references are also inscribed in this scene: contemporary viewers would have recognized the painting's relationship with popular posters, advertising the

${ }^{9}$ BAUDELAIRE. The Painter of Modern Life, p. 400. 
Folies, which lined the Parisian streets. By these technical means of fragmentation, distortion and broken brushwork, the painting re-presents the artist's initial encounter with the crowd. As a result, the viewer standing in front of the painting is immersed in the dynamic spectacle of people and paint-marks which trigger sensations of the fleeting and transitory and, in turn, transform his experience of reality.

As seen in Manet's painting, Baudelairean modernity initiates a breakdown of boundaries between art and life and between high art aesthetics and popular culture and shocks through defamiliarization. To follow this trajectory to Installation art, we must go directly to early twentieth-century Cubism, the art form from which contemporary art installations more directly issues. In Picasso's painting Ma Jolie (1911-12; FIG. 3) we can see how the spectator is even more fully immersed in the dynamic dissolution of the picture space and the objects and figures within that space. Ma Jolie (My Pretty One) represents a female figure, Picasso's current lover, holding a guitar. Here Picasso breaks down the closed forms with intersecting planes and brushwork, arranging them in rhythmic patterns that visually reverberate to signal the music that the woman strums on the guitar. ${ }^{10}$

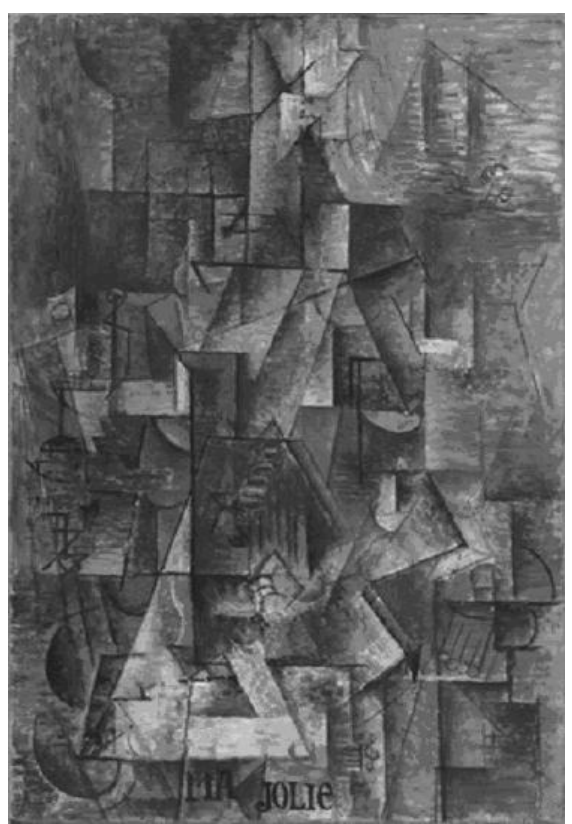

Figure 3 - Pablo Picasso, Ma Jolie, winter 1911-12. Oil on canvas, $100 \times 64,5 \mathrm{~cm}$. The Museum of Modern Art, New York. (C) 2013 Estate of Pablo Picasso/Artists Rights Society (ARS), New York

Ma Jolie not only references Picasso's personal life, but also popular culture and urban life. For one thing, the painting's title is inscribed in the painting in stencil-like letters and a staff and treble clef note. These letters simultaneously evoke a refrain from a popular song, the song's musical score-sheet and the posters advertising cabarets where popular songs were performed. Furthermore, by fragmenting these pictorial and popular references the artist presents multiple views of single figures and objects simultaneously. This visual simultaneity de-centers the spectator, who is now more actively engaged in mentally re-constructing the subject matter and

\footnotetext{
${ }^{10}$ The central triangular mass subtly indicates the shape of a woman's head and torso, and a group of six vertical lines at the painting's lower center represent the strings of a guitar and woman's hands.
} 
space. His eye wonders from foreground to background, from top to bottom, and in the viewing process repeats the artist's creative process. Just as the artist had done, the viewer must reflect upon his dynamic visual sensations and the fragments of information received from the picture surface, so as to reconstruct a reality that is both fleeting and transient. Picasso has transformed a familiar spectacle into an object of reflection and contemplation. Within our trajectory to Installation art, Ma Jolie represents a further refinement and simulation of modernity.

Dada and Surrealist artists, dating from the 1910s through the 1930s, followed the Cubist example of defamiliarizing the familiar. For these artists, the creative act of displacement constituted the artwork's singular aesthetic and transformative value. Marcel Duchamp's readymades exemplify this process, here seen in the Fountain (1917; FIG. 4), a urinal turned on its side, placed on a pedestal and signed by Duchamp's pseudonym Mr. Mutt. As Duchamp explained, "Whether Mr. Mutt with his own hands made the fountain or not has no importance. He CHOSE it. He took an ordinary article of life, placed it so that its useful significance disappeared under a new title and point of view - created a new thought for that object." ${ }^{11}$ Duchamp's ready-mades also demonstrate how Dada and Surrealist artists went further than the Cubists in compelling the spectator to extend-but never complete-the work of art. By experiencing the ready-made in his/her own time, the viewer brings his prior experiences, sensory responses and afterthoughts to the artwork's meaning. For Duchamp the spectator's performance is always a part of the creative process and product. As he stated, "All in all, the creative act is not performed by the artist alone; the spectator brings the work in contact with the external world by deciphering and interpreting its inner qualification and thus adds his contribution to the creative act."12 Thus the ready-made embodies and promotes the modern "Baudelairean" experience of the infinite, the fleeting, and the transitory: both the object's meaning and the viewer's mind are always in transition. This kind of performative, transitory engagement is also central to the aesthetic experience of Installation art. Like the ready-made, the Installation artwork can never be completed: each participant brings to and takes away a different understanding. Akin to Duchamp's ready-mades, the purpose of Installation art is to mediate the artist's creative act to the viewer's interpretative performance.

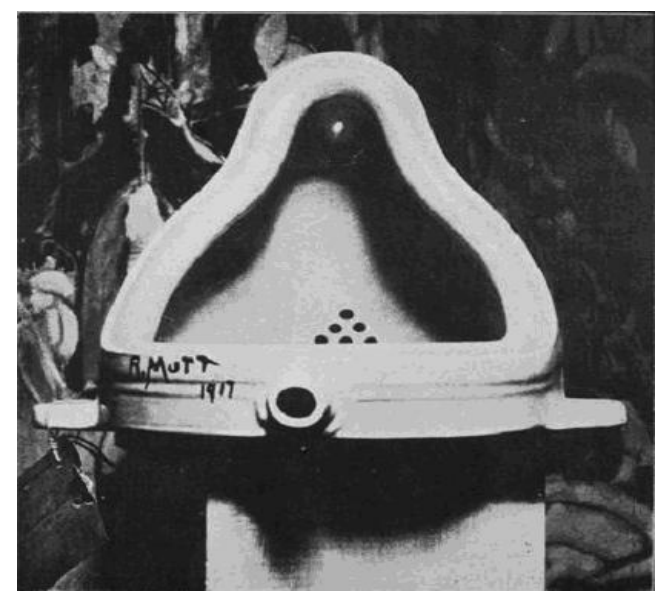

Figure 4 - Marcel Duchamp, Fountain, 1917 (original destroyed). Alfred Steiglitz photograph of original ready-made porcelain urinal turned on its back. Source: ARTstor Slide Gallery.

${ }^{11}$ DUCHAMP. The Richard Mutt Case, p. 248.

${ }^{12}$ DUCHAMP. The Creative Act, p. 77-78. 
The Surrealist poet André Breton further explained the aesthetic and social value of replacing ordinary reality with the extraordinary reality of the dream. He thus defined Surrealism: "[Surrealism] is based on the belief in the superior reality $[\ldots]$ of the dream, $[\ldots]$ the permanent destruction of all other [logical] mechanisms and to its substitution for them in the solution of the principal problems of life." ${ }^{13}$ Salvador Dali's and Marcel Duchamp's installations at the Surrealist Exhibition of 1938 show how the artists cultivated dream imagery with the strange combinations of everyday objects. The gallery lobby displayed Dali's Rainy Taxi, a taxicab rigged to produce a drizzle of water down the inside of the windows, a shark-headed creature in the driver's seat, and a blond mannequin crawling with live snails in the back. The corridor, titled Plus belles rues de Paris (The most beautiful streets of Paris), was lined with female mannequins, dressed by Duchamp and other artists and writers, wearing a bird cage, stuffed birds, and men's clothing, among other quotidian objects. The main gallery - displaying 200 artworks - was dimly lit with coal bags suspended from the ceiling and with sand and leaves covering the floor. As we shall see, surrealist objects and exhibition displays provided Installation artists with techniques for triggering free associations by subverting the rational/functional use of utilitarian objects and by exploiting the irrationality associated with dreams.

In the 1950s and 1960s the New York artist Alan Kaprow transformed the ready-made and free associations of the dream into an interactive work of art, calling these events "Happenings." Happenings were one-time performances, involving the spectator/audience, which occupied and transformed entire exhibition galleries and outdoor spaces. Because Kaprow's Happenings attempted to integrate art and life and to remove the boundaries between artist and observer, they stand as a direct prototype of installation art; in fact, the entire creative process is transferred to the spectator performer. Happenings also reunite the Baudelairean themes of modernity: 1.) transitoriness 2.) fragmentation; 3.) decentering and displacement of the viewing subject; and 4.) defamiliarization of the familiar. In a 1958 essay Kaprow introduced the Happening as a "concrete art" made of everyday materials such as "paint, chairs, food, electric and neon lights, smoke, water, old socks, a dog, movies" and stated that craftsmanship and permanence should be forgotten. ${ }^{14}$ The Happening also allowed the artist to experiment with body motion, recorded sounds, written and spoken texts, and even smells.

In his 1961 Happening, Words, spectators were invited to rearrange words painted on cardboard on the gallery walls. Another Happening, called "Fluids," involved bringing people into rooms and to various outside sites where large rectangular enclosures of ice blocks had been constructed; visitors were instructed to touch the ice, causing it to melt, and thus bringing the piece full circle.

\footnotetext{
${ }^{13}$ BRETON. The First Surrealist Manifesto, p. 452.

${ }^{14}$ KAPROW. The Legacy of Jackson Pollock, p. 9.
} 


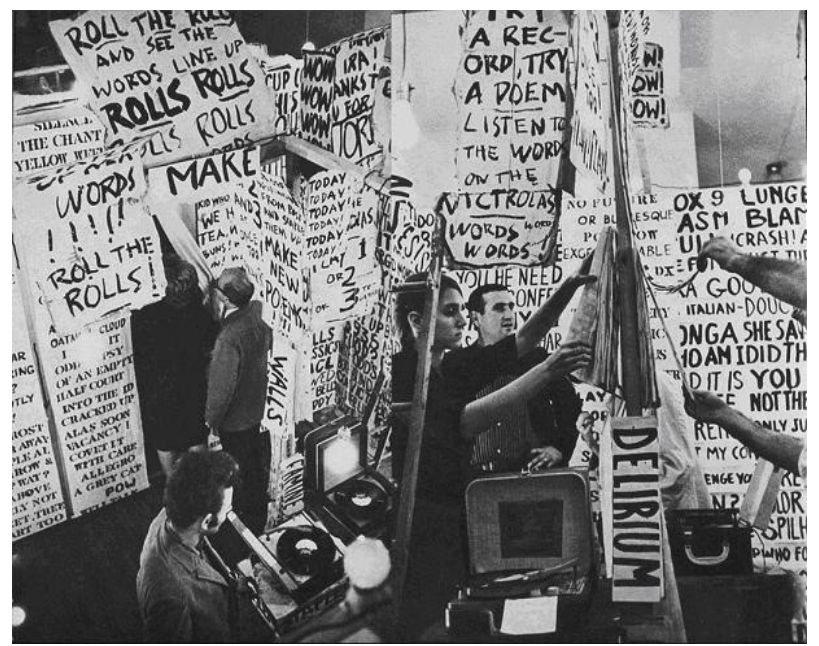

Figure 5 - Alan Kaprow, Words, 1971. Rearrangeable environment, lights and sounds Source: ARTstor Slide Gallery.

Each of these works heightens our sensory experiences and our physical and psychological awareness of our own body movements among a myriad of fragments from our material world, and thereby transforms our cognition and understanding of our presence in the world of phenomena. At the same time that we are mired in our own sensations we are also conscious of other bodies and performers. We thus become, like Baudelaire's "Painter of Modern Life," a kaleidoscope with a consciousness. We are also aware that we, too, are double-sided: each individual is both part of the crowd and separate from it. As I will now discuss in detail, these same performative acts and psychic effects are at the center of the Installation art works at Inhotim.

\section{The Baudelairean Trajectory at Inhotim: Mirrors and Reflections}

“As Inhotim's visitors peer through the kaleidoscopic surfaces of Olafur Eliasson's Viewing Machine (2001), listen to the earth's grumblings in Doug Aitkin's Sonic Pavilion (2009) or even feel the broken glass under their feet within Cildo Meireles' Através (1983-1989/2008)," their senses become the medium through which rational purposefulness becomes irrational play. As the rational connection to the world is ruptured "so too is the visitor's singular construction of identity as an embodied viewer." As visitors traverse Inhotim's garden pathways and interact with the artworks dispersed throughout, "they become part of a community of sensory explorers," and re-consider their bodies as part of the social body. ${ }^{15}$ To explore these transformative experiences I will discuss those installations that most effectively engage the spectator in a dynamic/ participatory experience that redefine social relationships and, in turn, our existence in the natural and man-made worlds. With this as my focus, I have selected works that incorporate mirroring devices and mirrored reflections as the means for disrupting the viewer's physical totality, de-centering his perception, and inducing self-reflection.

The installation works of Brazilian artist Hélio Oiticica and filmmaker Neville d'Almeida, are Inhotim's closest historical and conceptual link with Kaprow's Happenings and the Baudelairean

${ }^{15}$ BARCENA. The Senses at Play: Dan Graham at Inhotim, p. 13. 
tradition of modernity. Titled Block-experiments in Cosmococa - Program in Progress, $1973^{16}$ five room-sized environments occupy a single building at Inhotim. As Oiticica explained about Cosmococa, "[these block-experiments] are directed to the senses, so that through them and through 'total perception' individuals are led to a 'supra-sensation', i.e., an expansion of their ordinary sensorial capacity, so that they can discover their inner creative center and their dormant expressive spontaneity that has been conditioned by everyday life."17

In these works the artists created room-sized environments with swimming pools, hammocks, Styrofoam floors and objects, sand, balloons, and screen projections from 1970s pop culture icons - from Jimi Hendrix music to images of Marilyn Monroe. Each room variously exists as a place for swimming, stretching out, jumping, playing and dancing. Similar to the Happenings, the interconnection between art and life is rendered through the viewer's immersion in the world of familiar objects and symbols, which are rearranged in unfamiliar combinations, allowing us "to re-create ourselves as subjects in the unruliness of the senses." ${ }^{18}$ Here the spectator-performer becomes immersed in "a simultaneous mix of music and projected images on the walls and ceiling[.]" ${ }^{\prime 19}$ Although actual mirrors are not used, projected images reflect a world of fragmentation, randomness, and dematerialization.

Take, for example, Cosmococa 5 Hendrix War (FIG. 6) which consists of a space hung with crisscrossed lines of multi-colored hammocks. "Slides of images from the sleeve of Jimi Hendrix's War Heroes album, [outlined with] Neville d'Almeida cocaine drawings, are projected on to the walls and ceiling of the room. Visitors are invited to lounge in the hammocks and listen to Hendrix's music, thereby filling the space between the images and the music[.]"20 Here the visitor not only brings to life the otherwise static hammocks, but does so in infinitely unique ways. As a result, "Oiticica's interactive installations [produce] a cinematographic experience which envelops the viewer in a corporeal way." ${ }^{21}$ However, whereas the viewer expects a narrative development in the cinema, in the Cosmococa 5 room, that development is denied through the shifting and fragmented images of the album covers. Hendrix's face is also fragmented by the lines of cocaine, both a visual and material pun on the hallucinogenic drug and our own druglike delirium as we swing and sway in the hammocks.

\footnotetext{
${ }^{16}$ As curator-critic José Augusto Ribeiro explains, until Cosmococa was installed at Inhotim, the program existed without the environments ever having been installed: it existed only as photos, text and instructions. Ribeiro also explains that the title "Cosmococa" is derived from other words Oiticica had coined, such as "mancoquillage," "which results from the combination of Manco Capac - the name of a ruler of the Inca empire whose first and last name join the syllables 'Co' and 'Ca"' combined with maquillage, which is a type of painting, however cosmetic." (RIBEIRO. Hélio Oiticica and Neville d'Almeida, p. 148.)

${ }^{17}$ OITICICA, Hélio. Aparecimenro do supra-sensorial na arte brasileira (Dec. 1967). In: OITICICA, Hélio. Aspiro ao grande labirinto. Rio de Janeiro: Rocco, 1986. Translated and quoted in RIBEIRO. Hélio Oiticica and Neville d'Almeida, note 1, p. 149. (Emphasis added).

${ }^{18}$ RIBEIRO. Hélio Oiticica and Neville d'Almeida, p. 149.

${ }^{19}$ RIBEIRO. Hélio Oiticica and Neville d'Almeida, p.148.

${ }^{20}$ CC3-MAILERYN. Quasi Cinema (Block-Experiment in Cosmococa-Program in Progress).

${ }^{21}$ CC3-MAILERYN. Quasi Cinema (Block-Experiment in Cosmococa-Program in Progress).
} 


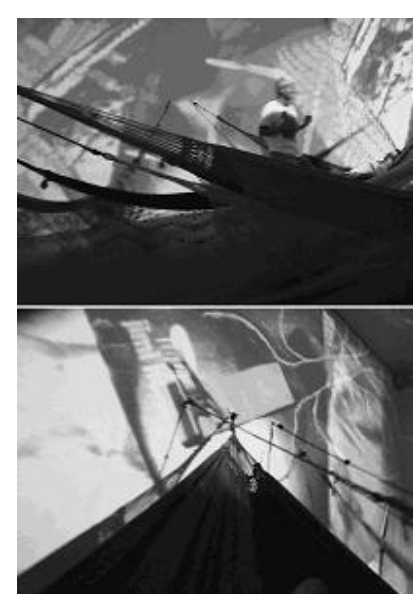

Figure 6 - Hélio Oiticica and Neville D’Almeida, Cosmococa 5 Hendrix War, 1973. Projectors, slides, hammock, soundtrack (Jimi Hendrix) and audio equipment, variable dimensions. Inhotim Institute of

Contemporary Art, Brumadinho

Photos: Bryan Barcena.

The cinematic embodiment of sensory experiences combined with surrealist dream fantasies are further recombined in Valeska Soares's Folly (2005-2009; FIG. 7). Unlike Oiticica's multiple installations constructed within a single building, other installations are single works enclosed in a single building. These free-standing enclosures make our engagement with the artwork much more striking in contrast with the natural environment. We experience this "shock of surprise" in approaching Soares's Folly. Emerging from a winding road along one of the large ponds in Inhotim gardens we begin to see a small-scale building structure, reminiscent of traditional garden decorations built to induce fantasies of exotic places or distant historical eras. As you get closer to Soares's Folly you realize that what seemed from the distance to be an open pavilion with a roof supported by slender poles, is actually a closed octagonal shape, with sides covered by mirrors reflecting the surrounding landscape. To enter the building one must step up to and walk around the raised pavilion platform to the door at the back of the structure, all the while seeing oneself immersed in nature. Upon entering, the natural order is reversed: mirrors that reflected the exterior landscape now dissolve the interior enclosure; daylight is replaced by a misty, nocturnal glow, emitted by video projections infinitely multiplied on the mirrored walls of an otherwise empty room. And here the spectator's immersion in nature is replaced by his immersion in ephemeral images of dancing figures that move in every direction. 


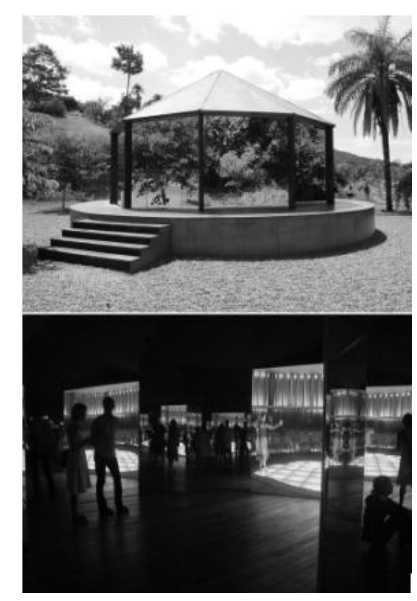

Figure 7 - Valeska Soares, Folly, 2005/2009. Wood, glass, air-conditioning, video transferred to dvd, 5', sound track "Look of Love." Inhotim Institute of Contemporary Art, Brumadinho

Top photo: Bryan Barcena.

Bottom photo: Mariana Gogu (http://www.flickr.com/groups/inhotim/pool/marianagogu/).

Originally Soares created this video, titled The Night for a solo exhibition at the Pampulha Museum of Art (Belo Horizonte, MG), housed in the old casino Pampulha designed by Oscar Niemeyer in the early 40s. ${ }^{22}$ The video shows images of (a female and two male) dancers dancing around the casino's stage floor to a soundtrack of a remixed version of Burt Bacharach's 1967 song "Look of Love" (1967). ${ }^{23}$ Appearing ghostlike, through veils of multiple overlaid images of the same dance sequences (created by video looping), ${ }^{24}$ the dancers seem to float in space as they approach and then drift away from each other. Soares's video explores the blurring of "the body's presence and absence, memory and imagination, love and dance," fantasy and reality. As visitors become performers in the artist's fantastical space, we too become part of the dancers' dance of desire and repulsion, inner and outer reflection, and public and private spectacle. This visual and psychic dualism evokes Manet's earlier play with mirror reflections and ruptures, signaling once again historical modernism's trajectory to postmodernism. Furthermore, like Baudelaire's painter of modern life, the participant-spectator of Soares's work is "a kaleidoscope with a consciousness."

If Soares's reflected mirror surfaces play with the dualities of imagined and real existence, Dan Graham's Bisected triangle, Interior curve, 2002 - a glass pavilion (FIG. 8), plays on the dualities of individual and social existence. Graham's work is a construction of mirrored glass and stainless steel, measuring a little over average adult height. As the title states, the external triangular structure is bisected by a curved interior partition. Visitors approach the pavilion, located next to a large pond, either by descending a tree-canopied, curved stone stairway or from a flat opening in the surrounding trees and hedges. What first appears as a non-descript

\footnotetext{
${ }^{22}$ Nine New Destinations: Valeska Soares, Press Release, Inhotim Institute of Contemporary Art, < http:// www.inhotim.org.br/novenovosdestinos/pt/release_valeska-soares.html >.

${ }^{23}$ Nine New Destinations: Valeska Soares, Press Release, Inhotim Institute of Contemporary Art, < http:// www.inhotim.org.br/novenovosdestinos/pt/release_valeska-soares.html >.

${ }^{24}$ Video looping is a video track that repeats the same sequence coincidently, but at different time intervals, so that the video track plays over and over again but in multiple timings. The remixed Bacharach soundtrack also emits overlays, loopings, of the musical/vocal score.
} 
glass pavilion is gradually transformed by the structure's flat and curved surfaces. Standing in front of the pavilion, the viewer becomes seduced by the kaleidoscopic play of the landscape shapes and colors reflected on its surfaces. As we have seen in Manet's Bar at the Folies Bergère, Graham's mirrors function as a de-centering device, rupturing the viewer's orientation and expectation for an illusionistic representation of reality. Here the spectator-performer is immersed in a constantly changing interplay of transience and fragmentation: the exterior and interior spectacles of nature and humanity are constantly multiplied, distorted, intermingled and transformed. Graham admitted to this kaleidoscopic and play effects in an interview where he described his site-specific work of Inhotim: "Mirrored glass made it into a photo opportunity. And the idea of an amusement park, a funhouse situation creating kaleidoscopic space." ${ }^{25}$

However, as the viewer encircles and enters the structure he becomes a kaleidoscope with a social consciousness. Now the viewer sees his own body ruptured, multiplied and dispersed among other bodies: he is at once viewer and viewed as an object. Shifting from playground to social arena, Graham's glass pavilion transforms the familiar into the unfamiliar, and thereby activates the individual's awareness of his multiple identities within the human and natural landscapes.

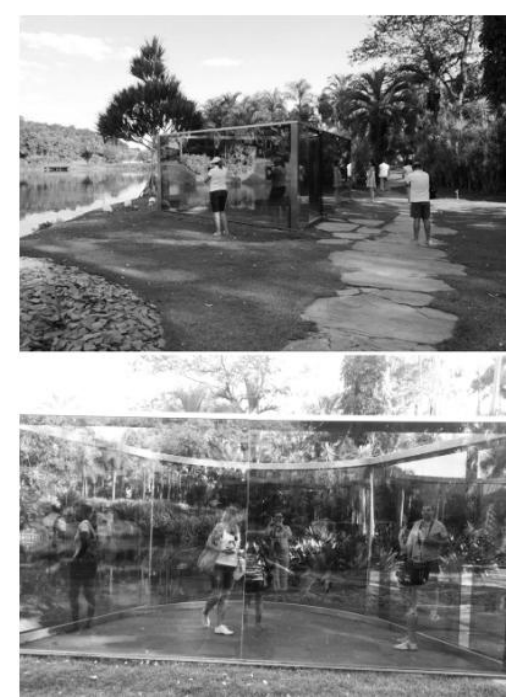

Figure 8 - Dan Graham, Bisected triangle, Interior curve, 2002. Mirroed glass and stainless steel, $220 \times 713 \times 504 \mathrm{~cm}$. Inhotim Institute of Contemporary Art, Brumadinho

Top photo: Bryan Barcena.

Bottom photo: Author.

Olafur Eliasson's Viewing Machine, 2001-2008 (FIG. 9), is literally based on the kaleidoscope principle. As with the original kaleidoscope, developed in 1817 (by Scottish inventor Sir David Brewster), Eliasson's Viewing Machine creates an effect of reflected light with six mirrors forming a hexagonal tube. The word "kaleidoscope" is formed from three Greek words which together mean "observer of beautiful shapes." ${ }^{26}$ In Eliasson's version, the viewer is invited to create his own beautiful shapes by moving the machine toward a point of interest either inside a gallery enclosure or outside amidst the infinite landscape. Ironically, the scale of viewing machine is

\footnotetext{
${ }^{25}$ METZ. Interview with Dan Graham, n. p.

26 < http://en.wikipedia.org/wiki/Kaleidoscope >.
} 
more like a massive telescope than the hand-held device that children play with. It requires one's entire adult body to move the apparatus and experience the spectacle that unfolds within. I have seen the Viewing Machine in both exhibition spaces at Inhotim, within the gallery and outside, but here I treat the outside installation, being most effective for the viewing subject's transformative gaze. Here the Minas landscape unfolds in all of its glory: multi-hued green vegetation, rugged mountain ranges, rich red soil and rock masses, and the boundless canopy of clear blue or cloud-streaked sky.

In the Viewing Machine the experience and the process of perception are central to Eliasson's interests. Here, rather than capping the kaleidoscopic device with colored glass, Eliasson uses angled mirrors to transform the actual surroundings into a dazzling and fragmented display. Since the viewer can rotate Viewing Machine on its base, he can control the colors and shapes that become fragmented before one's eyes. Given the machine's enlarged size and weight, causing a slower sequence of changes, the viewer becomes more contemplative of both his viewing process and the process through which perception can shape and alter our understanding of both conceived reality and the physical world around us. The work's title, however, is ironic, since the Viewing machine fragments and decomposes our vision of the surrounding landscape, rather than facilitates an orderly cognitive process. "This ironic play on words and expectations makes the impact of unsuspected fragmentation all the more extraordinary - if not shocking." 27 Eliasson, in his own writings, argues that having the sensuous experience of a new sight can "throw the world anew." ${ }^{28}$ It would seem that Eliasson strives to recreate the Baudelairean artist's facility of perception in the twenty-first century. With Viewing Machine, he encourages viewers to become, like the Baudelairean artist, "a kaleidoscope endowed with consciousness that with every one of its movements presents a pattern of life, in all its multiplicity."

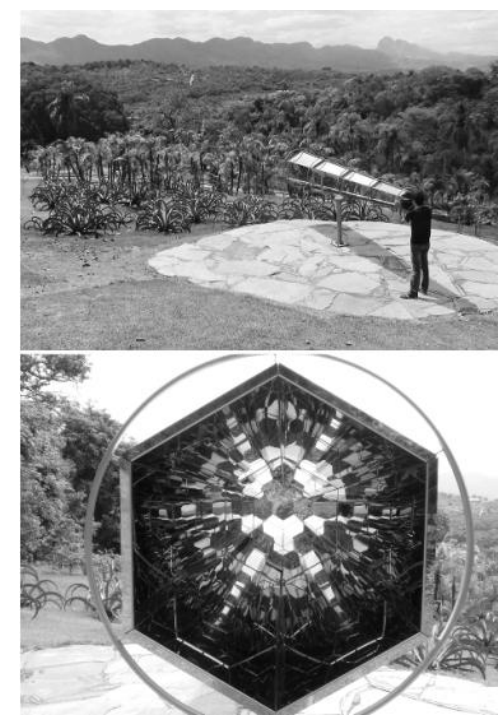

Figure 9 - Olafur Eliasson, Viewing machine, 2001-2008. Stainless steel. Inhotim Institute of Contemporary Art, Brumadinho

Top photo: Alina Lacerda (http://www.domusweb.it/en/art/ideal-museums/).

Bottom photo: Author.

${ }^{27}$ MAHAN. Olafur Eliasson's Viewing Machine: Kaleidoscopic Vision in the Twenty-First Century, p. 8. ${ }^{28}$ BIRMBAUM, Daniel. (Ed.). Olafur Eliasson. Innen Stadt Aussen. Köln: Verlag der Buchhandlung Walther König, 2010. p. 18. Quoted in MAHAN. Olafur Eliasson's Viewing Machine: Kaleidoscopic Vision in the Twenty-First Century, p. 14. 
While Graham's glass pavilion and Eliasson's Viewing Machine play with perceptual faculties, Brazilian artist Cildo Meireles' Através (Through) (1983-89, 2007; FIG. 10), plays with the intermingling of sight and sounds that condition our understanding of reality as embodied sensory experiences. Através is comprised of variously textured and assembled screens arranged in a 15-by-15-meter square labyrinth. As such, Meireles' installation offers the viewer an excursion through a shifting sequence of planes either suspended or anchored in space, as if one is immersed in Picasso's Cubist painting. As in the painting, the planes alternate between transparency and semi-transparency in apparently random sequences. But that is where Através's similarities with painting ends. Here planes are materialized as ordinary railings, wooden gates, metal fences, garden lattices, glass, paper and plastic dividers, including shower curtains and strings of beads. Furthermore, our experience of the enclosure is not only tactile but also auditory. The floor of the installation is covered in layers of broken glass shards. At first the shimmering sea of greenish-blue glass appeals to our perception, but walking on these slippery, uneven and shifting surfaces shatters our stability and sense of self-control. The cracking and creaking sound of the glass under our feet makes us feel unsteady and vulnerable. And once inside the labyrinth we are equally unnerved by the thought of exiting along the same treacherous path. We are, literally and metaphorically, trapped!

In this work, the layers of screens intensify our consciousness of enclosures and barriers and the functions they serve: protection or entrapment, chosen or imposed, open or closed, ephemeral or inert, personal or public, garden or prison. Two aquariums filled with translucent fish, shimmering and swarming under gallery lights, remind us of our own paradoxical and fleeting condition: we are subjects of confinement and movement and of concealment and exposure; we are both viewer and viewed as other visitors appear and disappear through the layers of screens. Finally, after traversing the numerous screens and barriers, we arrive at the center of the labyrinth, illuminated by an enormous ball made up of numerous layers of cellophane paper and tape. Is this a receptacle of spiritual enlightenment or of manufactured waste? Ultimately, our arrival at the center is a moment for contemplation and pause. Meireles once stated that "the journey through a labyrinth is premised on a thoughtful, attentive search. You have to walk, but with each step, you have to stop and think. That is the good thing about labyrinths. They help us to slow down." 29 Here as in Graham's Bisected Triangle and Soares's "Folly," physical and psychic self-reflections are mediated throughout the artwork, fragmenting our individual identity and restoring a collective one. Historically considered, Meireles's Através also provides a pause to reflect upon the Baudelairean trajectory that links early modern experiences of fragmentation and dualism with our contemporary condition.

${ }^{29}$ MEIRELES. Through the labyrinth: An Interview with Cildo Meireles, p. 41. 


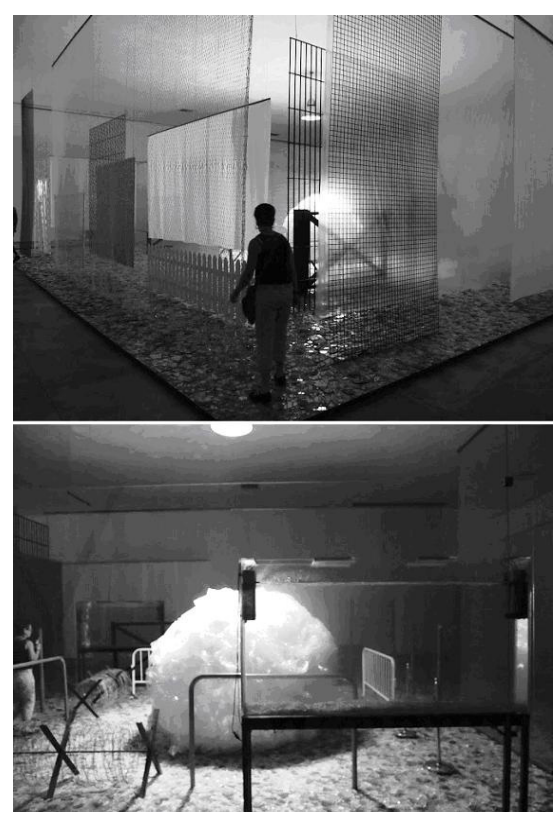

Figure 10 - Cildo Meireles, Através, 1983 -1989. Varied materials. Inhotim Institute of Contemporary Art, Brumadinho

Photos: Bryan Barcena.

Like Merieles's Através, Doug Aitkin's Sonic Pavilion (2009, FIG. 11) plays with aural faculties and invites us to consider our social relation with the earth and its resources. As the title suggests, the pavilion marks the site where the sounds of earth's movements take center stage and rise to the surface. Like Soares's Folly pavilion, Aitkin's design is determined by the spectator's performative role in approaching and entering the building and engaging with the empty space within. The Sonic Pavilion is designed in the shape of a circular building incased by glazed walls and topped by a flat white roof. As one nears the pavilion from a red brick path, the structure becomes visible above a hilltop. Rich, red soil and rocks, indigenous to the mining mountain range, seem to erupt from pavilion's foundation. This earthly, primeval matter tumble downs the hillside, contrasting with the machine precision and gem-like sheen of the structure's form..$^{30}$

Visitors enter the pavilion's interior by way of a gently sloping hardwood ramp that is carved into the hill and walled with concrete. The visitor's movement into the pavilion is directed from this outside ramp to an inside ramp which spirals around the interior walls and leads from to the pavilion's elevated ground level. From here, the tunnel-like ramps open up to a luminous-but empty-interior. Inside, the ramp becomes a spiraling platform, providing a bench for visitors to sit on, and forming a wainscot for the continuous glass partition around the periphery of the structure. Ironically, the glass enclosure prohibits a continuous transparent view of the surrounding forest and mountain range. Only segments of the landscape are clearly visible from any one position the viewer chooses along the periphery, while the rest appears as though through a deep fog. Aitken achieved this effect by coating the glass walls with lenticular film that renders the glass semi-opaque. ${ }^{31}$ Two holes pierce the center of the room; one hole

${ }^{30}$ The description and interpretation of Sonic Pavilion are adapted from BENDER. Doug Aitken's Sonic Pavilion (2009).

${ }^{31}$ EXCLUSIVES: Doug Aitken, n. p. 
cuts through the ceiling to allow in a shaft of light that forms a circle on the floor as it moves throughout the day. At noon the light beam centers over the second hole in the center of the floor. The hole in the floor represents the heart of the project. The viewer can only see its beginning, rimmed with steel inscribed with the artist's name, the name of the installation, and "Hole Depth 202 meters - 663 feet." From this center-point, the visitor can turn on his own axis and, in the process, gain a clear, transparent, continuous view of the panoramic landscape outside.

"The inscription refers to the one-mile deep hole burrowed into the hilltop. The drilling, along with the construction of the pavilion, took five years to complete. Once the hole was excavated, Aitken lowered geo-microphones into the hole and accelerometers in order to amplify the interior sounds of the earth: its rotation and the shifting of seismic plates." ${ }^{32}$ The resulting sound is conditioned by chance, ranging from a low, steady rumble to the sporadic, higher-pitched moment of friction. The sounds are amplified and emitted through eight hidden speakers placed around the room. Aitken discussed the eternal quality of Sonic Pavilion, which he described as having "no beginning and no end, deep-rooted, pure, and direct." ${ }^{33}$ For the viewer, the eternal is only a transitory effect, a transformative one nevertheless. Once we leave the pavilion via the same spiraling ramp and concrete tunnel through which we entered, we re-enter the forested terrain more attuned to nature's symphony that resounds above the earth's surface. Viewed within the Baudelairean trajectory, the Sonic Pavilion continues to unify the eternal with the transitory and to make the ordinary extraordinary.

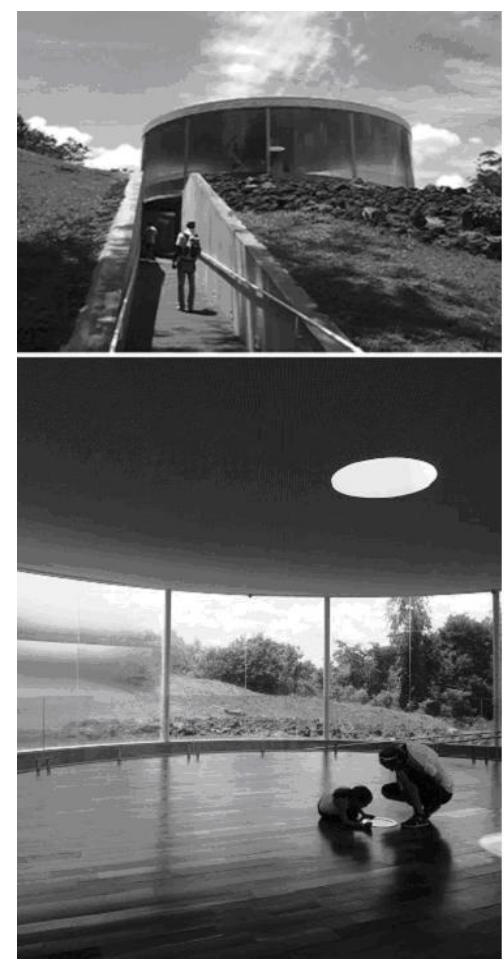

Figure 11 - Doug Aitken, Sonic Pavilion, 2009. Varied materials. Inhotim Institute of Contemporary Art, Brumadinho

Photos: Bryan Barcena.

\footnotetext{
${ }^{32}$ EXCLUSIVES: Doug Aitken, p. 3. For Aitken's use of computer technology see: FINKEL. The video artist uses the power of sound - and silence - to define his sculptural environments, n. p.

${ }^{33}$ KIM-COHEN. The Hole Truth: On Doug Aitken's Sonic Pavilion, p. 100.
} 
In closing, I would like to suggest how Inhotim's botanical gardens, carved out of a vast forest range and a rocky mining terrain, mirrors the transformative process of the Installation art that the museum contains. During our pilgrimage from one pavilion to another, we traverse alternating sequences of open natural space and, then, the rarefied space of the installation enclosures. This dynamic dualism between "nature" and "art" is subtly choreographed to facilitate the viewer's ritual performances through which he is transformed. Yet, the Inhotim experience is also transient: at the end of the day we must return to the parking lot and go home. Reflecting on this experience, Inhotim becomes an Installation artwork writ large: it challenges its visitors to extend our heightened senses and altered perceptions to our ordinary worlds in some extraordinary and surprising way.

\section{A}

RESUMO

Este artigo explora a virada participativa na arte da instalação como parte da trajetória da modernidade baudelairiana até a pósmodernidade do século XXI, representada por Inhotim, museu de arte contemporânea ao ar livre e jardim botânico, em Brumadinho, Minas Gerais. Em seu ensaio de 1862, "O pintor da vida moderna”, Charles Baudelaire definiu a modernidade como evanescente, transitória e fragmentária. A modernidade baudelairiana iniciou uma ruptura de fronteiras entre a arte e a vida, e entre a estética das Artes e a cultura popular, que continua nas instalações artísticas atuais. Nos locais das instalações, o espectador é forçado a expandir - em vez de completar - a obra de arte, em seu próprio ritmo, bem como suas experiências anteriores e reflexões posteriores. A mudança de uma obra de arte isolada para uma vivenciada não apenas complica o modo e o lugar em que as obras de arte são vistas, mas também radicaliza os materiais que constituem a obra de arte. Quer esses materiais sejam extraídos da esfera cotidiana, quer sejam extraídos de tecnologias complexas, cada obra passa por um processo de desfamiliarização e reativação para produzir a experiência estética transformadora. As instalações desse museu a céu aberto levam o espectador a uma experiência dinâmica e participativa com as relações espaciais, temporais e materiais que definem a própria essência da reciprocidade da arte, ou contrastam com o mundo, tanto o natural quanto o construído. É o cenário rarefeito do Jardim Botânico de Inhotim que faz com que a experiência participativa e transformadora se torne central para o encontro estético com a arte da instalação.

PALAVRAS - CHAVE

Inhotim, instalação, modernidade baudelaireana, pósmodernidade 


\section{WORKSCITED}

BARCENA, Bryan. The Senses at Play: Dan Graham at Inhotim. Unpublished paper written for the seminar "Global Installation Art" (Fall 2011).

BAUDELAIRE, Charles. The Exposition Universelle (1855). In: BAUDELAIRE, Charles. Art in Paris 1845-1862: Salons and Other Exhibitions. Translated and edited by Jonathan Mayne. Oxford: Phaidon, 1965. p. 121-143.

BAUDELAIRE, Charles. The Painter of Modern Life. In: BAUDELAIRE, Charles. Selected Writings on Art and Literature. Translated and edited by P. E. Charvet. London; New York: Penguin, 1992. p. 390-435.

BAUDELAIRE, Charles. Salon of 1846: XVII of the Heroism of Modern Life. In:

BAUDELAIRE, Charles. Selected Writings on Art and Literature. Translated and edited by P. E. Charvet. London; New York: Penguin, 1992. p. 104-107.

BENDER, Stephanie. Doug Aitken's Sonic Pavilion (2009). Unpublished paper written for the seminar "Global Installation Art" (Fall 2011).

BISHOP, Claire. Installation Art: A Critical History. New York: Routledge, 2005.

BRETON, André. The First Surrealist Manifesto (1924). In: HARRISON, Charles; WOOD, Paul (Ed.). Art in Theory, 1900-2000: An Anthology of Changing Ideas. Malden, Mass.: Blackwell, 2002. p. 447-453.

CC3-MAILERYN. Quasi Cinema (Block-Experiment in Cosmococa-Program in Progress). Museu d'Art Contemporani de Barcelona, Collection/Holdings. Available on: < http://www. macba.cat/en/cc3-maileryn-quasi-cinema >. Accessed: Mar. 2012.

DUCHAMP, Marcel. The Richard Mutt Case (Letter to The Blind Man, May 1917). In: HARRISON, Charles; WOOD, Paul (Ed.). Art in Theory, 1900-1990: An Anthology of Changing Ideas. Oxford, UK: Blackwell, 1993. p. 248.

DUCHAMP, Marcel. The Creative Act (1957). In: LEBEL, Robert. Marcel Duchamp. New York: Paragraphic Books, 1959. p. 77-78.

EXCLUSIVES: Doug Aitken. AnOther Magazine, February 2, 2010. Available on: < http://www. anothermag.com/exclusives/dougaitken>. Accessed: Mar. 2012.

Acknowledgements:

This article is based on my 2012 Fulbright Core Scholar research project "Trajectories of Baudelairean Modernity: Brazil's Inhotim in Context" and my graduate seminar, "Global Installation Art," which I first taught at my home institution, Florida State University (Fall 2011) and subsequently at my host institution, Universidade Federal de Minas Gerais (March-April 2012). The Fulbright grant allowed me to study Installation artworks on site at Inhotim Institute of Contemporary Art and Botanical Gardens and to discuss the museum's design concept and collection with curators, Allan Schwartzman, Rodrigo Moura, Jochen Volz, Lucas Sigefredo, Tiago Batista, and with founder, Bernardo Paz. The Baudelairean themes discussed in this article were developed in the FSU seminar, upon which students developed research papers on individual artworks at Inhotim. Three of those papers were especially informative, whose authors I wish to credit here: Bryan Barcena, Nicole Mahan and Stephanie Bender. I also want to extend a special thanks to Bryan Barcena for assisting me with onsite photography at Inhotim, while visiting the museum in March 2012, and to Adriano Gomide for sharing information from his doctoral thesis, a comparative study of contemporary art collections at Inhotim and the Saatchi Gallery. 